\title{
Murals and their evolution and typology in the space of the urban environment on the example of Kyiv
}

\begin{abstract}
:
Over the past few years, murals have actively and firmly entered into the fabric of the architectural environment as one of the most powerful artistic means of urban art. According to the latest statistics, Ukraine, and Kyiv in particular, tops the list of leaders of the countries with the largest number of murals. Based on the historical context, the murals performed a social and propaganda mission. Already in the XXI century, Ukraine has experienced two revolutions. And they became a powerful impetus for the active manifestation of "street art" on free surfaces. But in contrast to the monumental and decorative compositions of totalitarian art, which still adorn the cities of Ukraine, the artistic and graphic language has changed. Young designers in modern graphic trends, form an updated visual representation of established stylistic solutions.

The purpose of the article is an attempt to determine the historical conditions of the murals' development, the features and principles of their solutions in the city space, as well as modern and promising means of implementation. The article discusses the factors and conditions of the evolution of modern murals, their typology and thematic focus, techniques and means of spatial composition and artistic solutions.
\end{abstract}

Key words: murals architectural environment, evolution, typology, urban landscape, Kiev

\section{INTRODUCTION}

Over the past few years, murals have actively and firmly entered into the fabric of the architectural environment as one of the most powerful artistic means of urban art. Scientists from different countries studied the phenomenon of murals and considered their phenomenon from different perspectives (GralińskaToborek, 2014, p. 85-99; Gastman, Neelon, Smyrski, 2007, 384 p; Kais, 2015, 20 p; Shpetna, 2020, p. 150-156; Kolisnyk, Ponomarova, 2019, p. 62-73; Havrylash, 2018, p. 235-244; Lolina, 2019, p. 84-87; Gryglewski, Ivashko, Chernyshevet al., 2020, p.57-88; Kozub, 2018, p. 33-36; Ostapenko, 2017, p. 51-52). The most famous are the works of Polish researchers (Gralińska-Toborek, 2014, p. 85-99; Kozub, 2018, p. 33-36), American scientists (Gastman, Neelon, Smyrski, 2007, 384 p), Ukrainian scientists and artists (Shpetna, 2020, p. 150-156; Kolisnyk, Ponomarova, 2019, p. 62-73; Havrylash, 2018, p. 235-244; Lolina, 2019, p. 84-87; Gryglewski, Ivashko, Chernyshevet al., 2020, p. 57-88). In various publications, murals were considered as a communicative component in urban and modern civic space (Kais, 2015, p. 20), as a means of social communication, including from the point of view of sociology, psychology and content (Shpetna, 2020, p. 150-156; Kolisnyk, Ponomarova, 2019, p. 62-73). Ukrainian researchers mainly consider murals as an artistic and visual form of Contemporary Art (Havrylash, 2018, p. 235-244; Lolina, 2019, p. 8487). Some researchers have turned to classifications of murals by subject and genre, as well as by communication system (Ostapenko, 2017, p. 5152). At the same time, the issues of their evolution and modern typology to some extent remained out of the attention of researchers and were not comprehensively considered.

\section{EVOLUTION}

In the first half of the twentieth century, in the wake of the revolutionary movement in Mexico, the artists of the "big three" - D. Rivera, H. K. Orosco, D. A. Siqueiros laid the foundations for the transmission of visual messages through works of monumental art. Thanks to them, the walls of buildings became artistic canvases. Muralism (painting on the walls of architectural buildings and structures) became a certain tool that directed the masses to revive and form new values in society. Before the advent of Mexican muralism, the social movement had never had such a vivid representation in works of art, even at such a high professional level. Probably because the artists took the call of the avant-garde masters too literally to leave the workshops for the street. Beginning with the revolutionary movement for the independence of Mexico, the murals became a reproduction of the most pressing problems of society: the people's liberation struggle; the desire of countries for self-determination; expanding the boundaries of cooperation; development of science, technology and engineering; defining national identity and hope for a bright future.In 
addition to purely social problems, the murals of the Mexican Revolution contributed to the revival of wall painting, which influenced the global development of so-called street art, which continued in the United States in the 1930s and eventually spread to other continents.

Kazimir Malevich, a theorist of Suprematist art, promoted revolutionary ideas of serving to the masses art and considered the local space to be one of the components of its active functioning. Therefore, in the 20-30s of the twentieth century in the USSR, the ideas of Mexican muralists found a response and actively promoted new revolutionary ideas, but received their own graphic language and style.

In modern Europe, the popularity of murals began much later, only in the 80s, and this was also facilitated by revolutionary changes, namely, the historical events of the destruction of the Berlin Wall. The society was ready to visually perceive acute political problems with updated artistic means. Creative personalities "went beyond" the classic poster art and reproduced modern messages in the popular graphics inherent in street art. A similar situation was observed during the political events in Poland and during the collapse of the former Yugoslavia - political images and slogans supported and reproduced popular sentiments.

In the vast expanses of the Soviet space until the 80s, before the time of the so-called "perestroika", you can notice the search for figurative language, plastic solutions, color combinations and reproduction techniques in artistic and monumental works. Although in general, the works of that period tend to be posterlike and decorative, which makes them visually the same type. Popular techniques for creating such panels were "fresco", "sgrafito", "mosaic" and various types of "bulky" relief images that decorated free planes on buildings of unpretentious typical development. Attempts to diversify unified and standardized buildings led to the appearance of really interesting artistic objects in the urban architectural environment thanks to monumental panels. The 80 s and 90 s were marked by the appearance of picturesque and decorative panels with neutral themes and complicated compositional solutions in the urban environment. It is during this period the foundations are laid for further development and implementation of individual graphic solutions. In further monumental projects, the author's visions, philosophical ideas, symbolic combinations and colorgraphic solutions are clearly traced.

At the beginning of the 21st century, Ukraine experienced two revolutions. They became a powerful impetus for the active manifestation of "street art" not only on fences and advertising structures inherent in the manifestations of street art, but also on the free vertical surfaces of buildings of impressive size. Street art quickly responded to changes in society by using free planes of buildings in the city center for graphic visualizations. It has become a common practice to invite foreign artists from different countries of the world, which has integrated domestic mural art into global content. This is confirmed by the annual entry of Kyiv murals in the rating of the best murals in Europe and in the world. The use of revolutionary messages and vivid national motifs only added distinction and originality to the Kyiv murals and allowed to identify certain historical and cultural objects of tourist visits. The thematic and figurative content of murals on Kyiv houses is quite diverse: from depictions of historical events and figures, political problems of our time to the ecology of the environment and human relations. The reproduction of these trends takes place against the background of an experimental search for unusual compositional solutions and forms of self-expression through metaphor, hyperbole, symbolism, surrealism and other forms of artistic visualization. In the modern formula of interaction between a person and a city, murals become a powerful tool that significantly complements the formation and updates the perception of the architectural environment, obeying it or, conversely, contrasting with it. Regardless of the size, theme, technique of reproduction, etc., murals create a meaningful and harmonious content of the environment and, often, act as an artistic dominant in urban planning solutions.

\section{TYPOLOGY}

The authors of this article consider it appropriate to classify the phenomenon of murals according to the following characteristics:

1. By urban planning / environmental characteristics (at the urban planning level).

2. By placing it against the background of a building (at the building level).

3. By topic.

4. By compositional and artistic-figurative solutions.

5. According to the technique of execution.

\section{At the urban planning level, the following classifications should be distinguished:}

\subsection{Murals that are located in a historical and non-} historical environment.

Kyiv's architecture is remarkable for its historical center, where the significant events of the two revolutions "Orange" and "Dignity" took place, which significantly influenced the development of the phenomenon of murals in Ukraine. Most of them, located in the area of historical buildings of Kyiv, are distinguished by a certain delicacy, balanced presentation of information and graphics. One of the most significant murals is a portrait of Serhiy Nihoyan, a Euromaidan activist and the first victim of the events of 2014 (II. 1a). The mural is made in a combined graphic technique: it is not just painted, but partially "embossed" into the wall. This technology of execution was dictated by the peculiarity of the old brickwork with a layer of plaster. The city center is decorated with a number of portraits of famous historical figures who appeared precisely because of the revolutionary events. Murals of historical figures - M. Hrushevsky, P. Skoropadsky reproduce outstanding personalities of the First Ukrainian Revolution of 1918-1920. (II. 1b,c). 


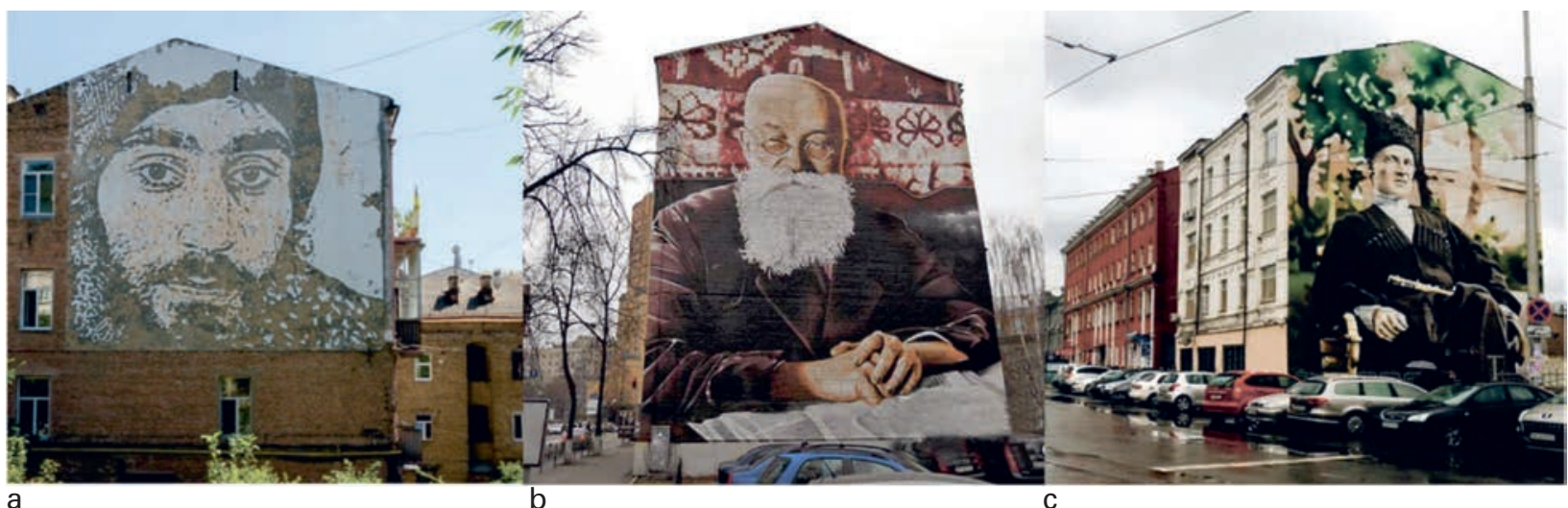

II. 1. Murals that are located in a historical environment with portraits of historical figures: a - S. Nigoyan, https://platfor.ma/magazine/text-sq/ street-heroes/ura-mural/; b - M. Hrushevsky, http://www.hroniky.com/news/view/5645-naiiaskravishi-muraly-kyieva-foto; c - P. Skoropadsky, http://www.hroniky.com/news/view/5645-naiiaskravishi-muraly-kyieva-foto (access: 12.11.2021)

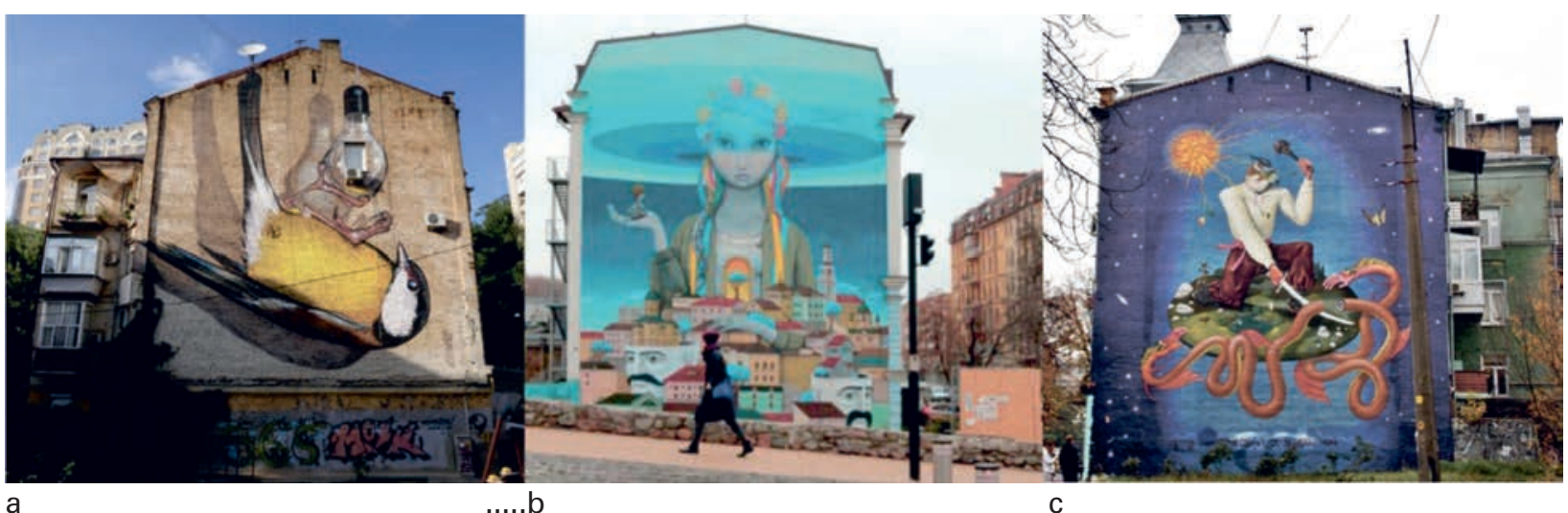

II. 2. Murals that are located in a historical environment: a - animalistic, https://chudokiev.com/interesnyie-mesta/muraly/mural-svoboda/, b - fairy-tale-patriotic images, https://www.bbc.com/ukrainian/ukraine_in_russian/2015/12/151216_ru_s_mural_kyiv; c - mythological creatures, http://www.hroniky.com/news/view/5645-naiiaskravishi-muraly-kyieva-foto (access: 12.11. $20 \overline{2} 1$ )

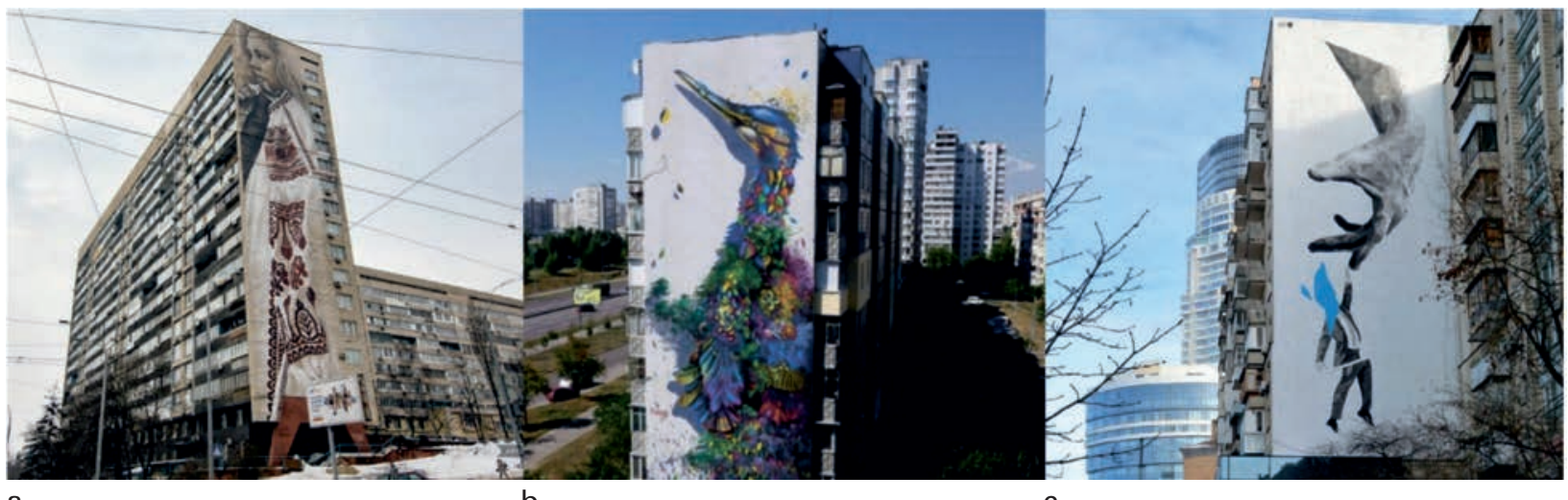

a

b

C

II. 3. Murals that are located in a non-historical environment: a - https://dayting.com.ua/ru/muralyi-na-pecherske-v-gorode-kiev; b - https://kiev.zagranitsa.com/article/4022/15-samykh-krasivykh-muralov-kieva-kotorye-stoit-razyskat

c - https://zeft.in.ua/murali-pecherskogo-rajonu-kiyiv (access: 12.11.2021)

The walls of old houses in the historic environment are decorated not only with portraits. Sometimes fairy-talepatriotic compositions and animalistic images saturated with mythological creatures look spectacular and attractive (II. 2).

It is worth noting that a significant amount of work in the historic center of the city was performed with maximum preservation of the authenticity of the surfaces of buildings.
Modern, typical development are the opposite of the historic environment Although today we see significant variability of new buildings, even in "sleeping" areas, their uniformity still occurs. Therefore, the murals turned out to be the very artistic means thanks to which it is possible to diversify the urban environment, to try to give a modern renewed look to the morally obsolete 
Soviet buildings, where minor renovations are taking place that do not significantly change the appearance of neighborhoods. The appearance of murals on the free planes of prefabricated houses of different ages diversifies the homogeneity of avenues, squares, squares and residential yards. A number of interesting works that have a long distance for contemplation and attract attention on the avenues of Kyiv should be noted (II. 3).

Separately, we should note the recent appearance of a large number of small murals in the confined spaces of residential courtyards and playgrounds. Although in their style and subject matter, they tend more towards works inherent in street art, because they do not have the meaningful load that murals carry. These are attractive images of cartoon characters, comics, or animals and flowers. (II. 4)

\subsection{Murals that are subordinate to the environment and contrast with it}

An example of subcontracting with the environment can be works of art that organically "fit" into urban architecture and complement it with interesting subjects. On the mural "Disappearing Sperm Whale», an air animal is firmly tied with ropes to the building. (II. 5)
These works adorn different areas of the city. They are visible and known to the residents.

Solutions of murals, which seem to "break into" the existing environment and very actively attract the attention of ordinary citizens, are the opposite, subcontracting. Such active images also fulfill certain missions: characteristic images, sometimes symbolizing certain human states and feelings. (II. 6)

\subsection{Ensemble and individual solutions}

In both modern and historical buildings, you can find and distinguish interesting ensemble solutions - a combination of several vertical planes of buildings into one integral composition or several thematic images that are subject to the rhythm of architectural construction. The phenomenon of painting or so-called supergraphics of residential complexes in Kyiv appeared in 1983 in the residential area of Troieschyna to diversify the typical prefabricated construction. But such innovations were very difficult to perceive by Soviet architectural authorities, which hindered the further development of this area (II. 7a)

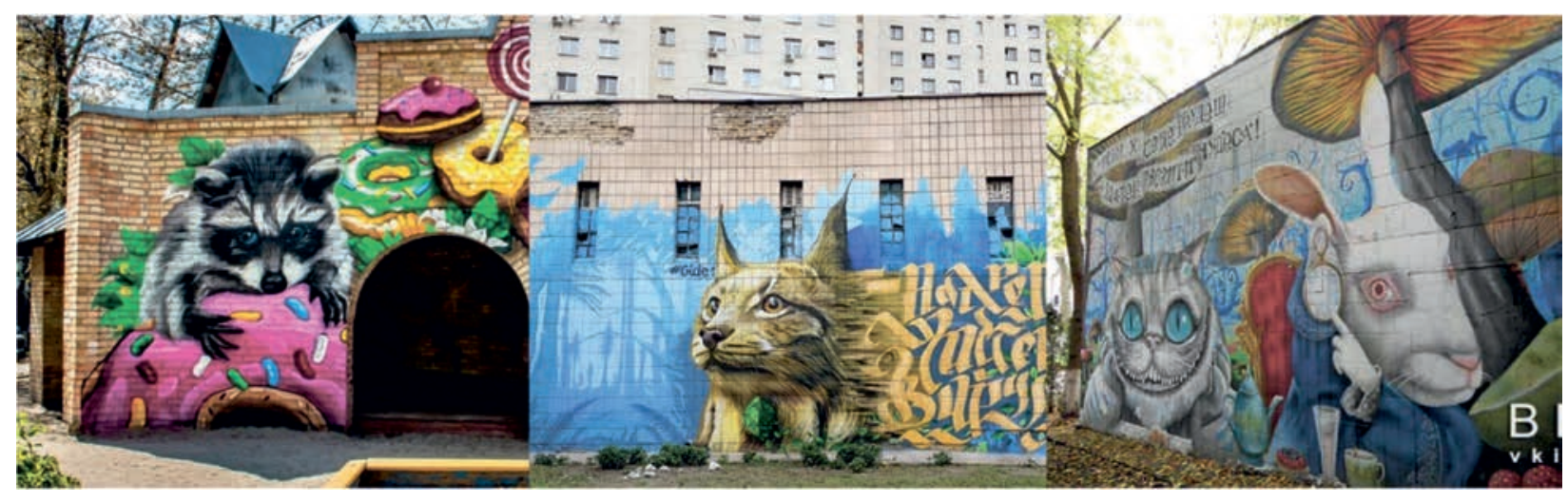

a

b

C

II. 4. Murals that are located in a non-historical environment (in enclosed spaces of residential yards and playgrounds):

a - https://nashkiev.ua/novosti/enot-i-ponchiki-na-oboloni-poyavilsya-ochen-milyy-strit-art-foto.html

b - https://vechirniy.kyiv.ua/news/26839/

c - https://vkieve.net/street-art/mural-alisa-v-strane-chudes (access: 12.11.2021)

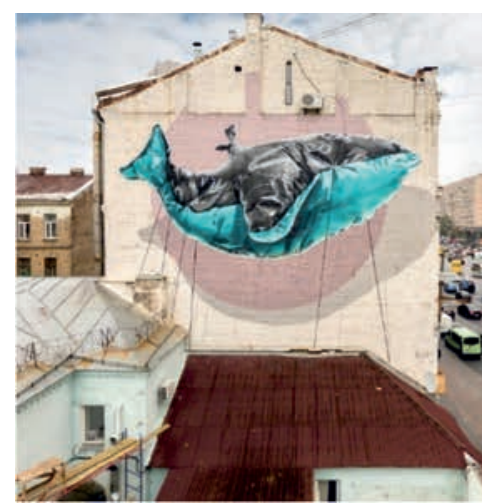

a

II. 5. Murals that are subordinate to the environment:

a - https://kievvlast.com.ua/news/v-kieve-poyavilsya-mural-s-ischezayushhim-kashalotom-foto

b - https://bykvu.com/ua/bukvy/30741-v-kieve-na-troeshchine-poyavilsya-odin-iz-samykh-vysokikh-muralov-v-mire/

c - https://www.44.ua/news/817743/na-fasade-kievskogo-doma-francuzskij-muralist-sozdal-lovkogo-celo (access: 12.11.2021) 


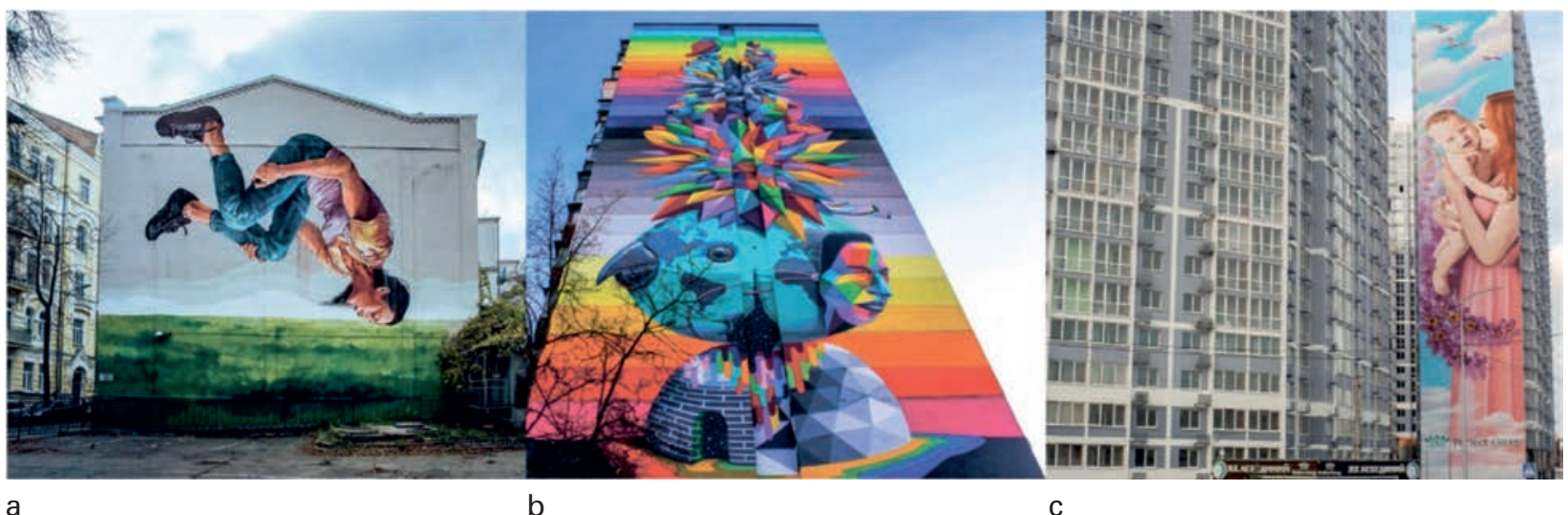

II. 6. Murals that contrast with the environment:

https://lookmytrips.com/5701a387ff93676b4f0e2ff0/mural-rizatdinova-ff9367

https://zeft.in.ua/murali-svyatoshinskogo-rajonu-kiyiv/

https://lebedinyiy.com.ua/ua/news/u-lebedynomu-novyj-mural/ (access: 12.11.2021)

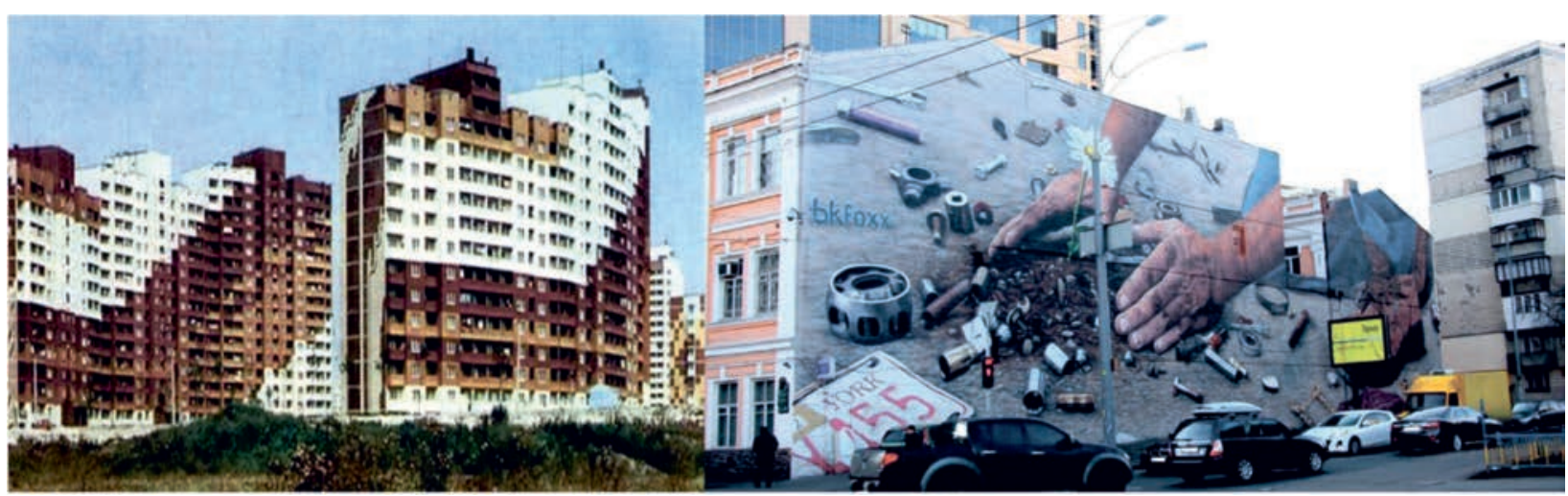

a

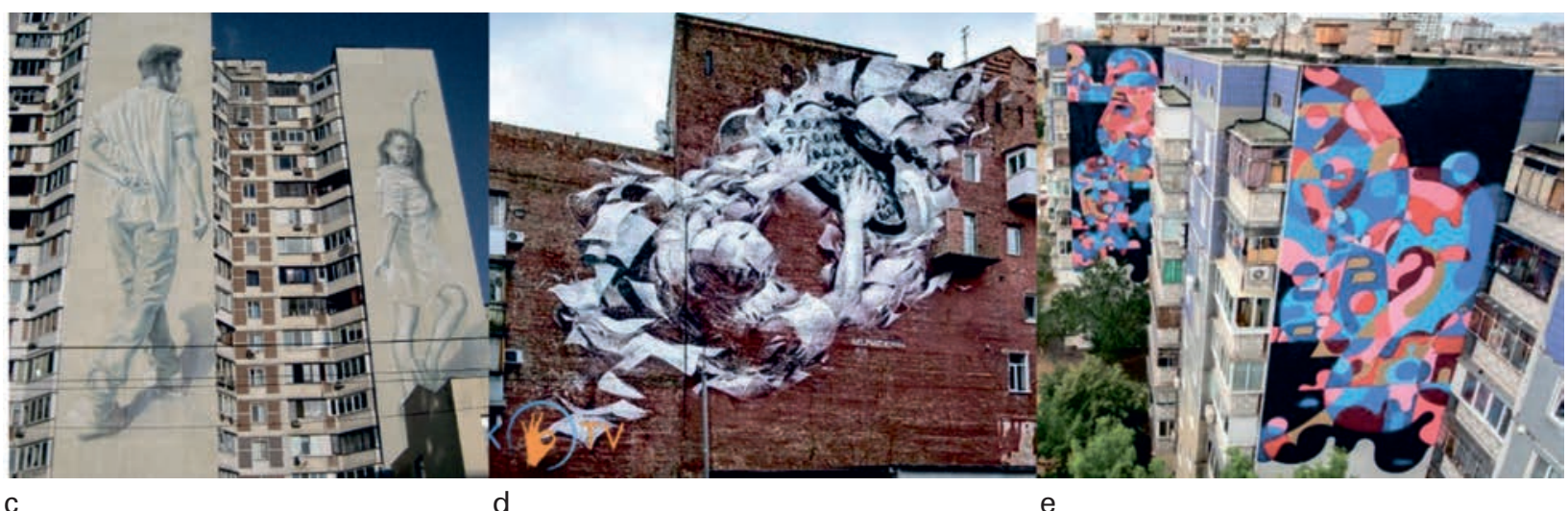

II. 7. Examples of ensemble solutions:

a - https://mistosite.org.ua/uk/articles/muraly-vt\%D1\%96lennya-symvol\%D1\%96chnoyi-vlady-dlya-zm\%D1\%96ny-obrazu-m\%D1\%96sta b - https://www.obozrevatel.com/city/journal/10-samyih-neveroyatnyih-muralov-ukrainyi-rejting-ot-cityoboz.htm

c - https://vesti.ua/kiev/156630-v-kieve-pojavilis-muraly-bliznecy- https://oktv.ua/turizm/dostoprimechatelnosti-kieva/mural-selfmademan $\mathrm{d}$ - https://chudokiev.com/interesnyie-mesta/muraly/mural-tanecz/

e - https://vesti.ua/kiev/156630-v-kieve-pojavilis-muraly-bliznecy (access: 12.11.2021)

Modern solutions do not cover such a huge space and are more local and thematic. In historical and adjacent territories, murals are sometimes placed on a plane formed by two or three buildings. A very successful solution for the surface of a complex configuration of three old buildings is the mural "Rise from the mud.» In 2017, it was included in the top 10 best murals in the world. (II. 7b) The work «Journalists» is similar to it. (II. 7d)
Single mural solutions often intersect closely with those that contrast with the surrounding buildings. These are images that are independently located on the selected vertical, often end plane, and sometimes serve as a visual compositional center of the architectural environment. (II. 8) 

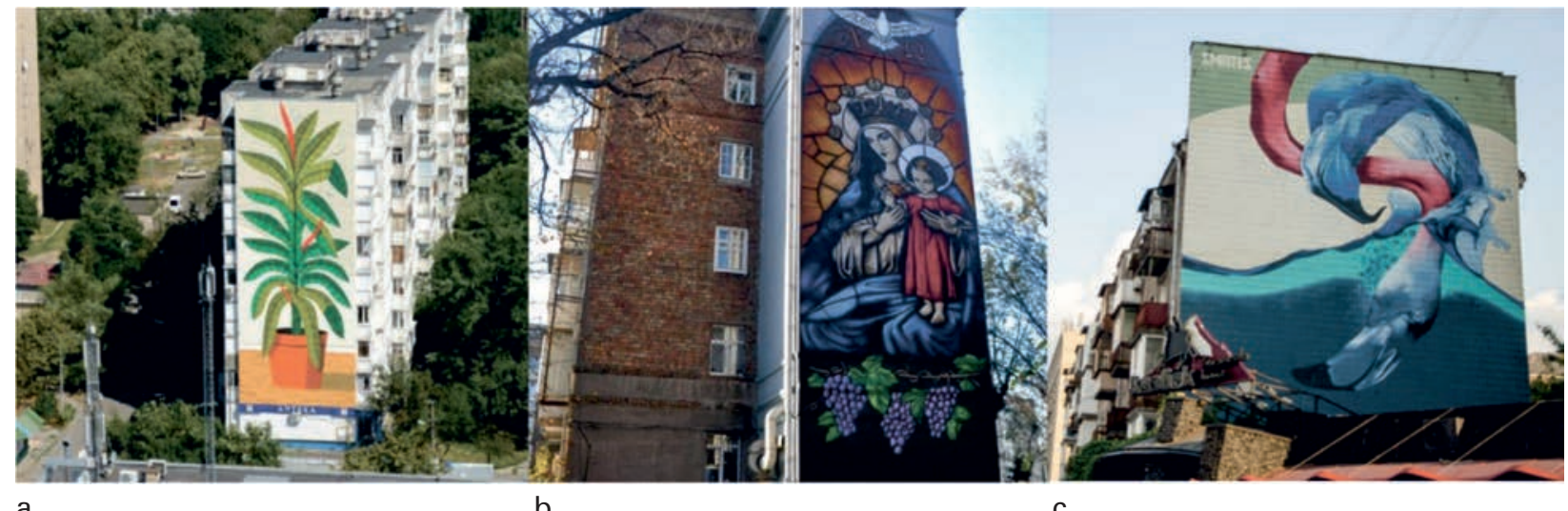

a

II. 8. Examples of individual solutions:

b

C

a - https://www.bbc.com/ukrainian/multimedia/2016/10/161007_new_murals_kyiv_gallery_ag

b - https://zeft.in.ua/murali-svyatoshinskogo-rajonu-kiyiv/

c-https://zeft.in.ua/murali-pecherskogo-rajonu-kiyiv/ (access: 12.11.2021)

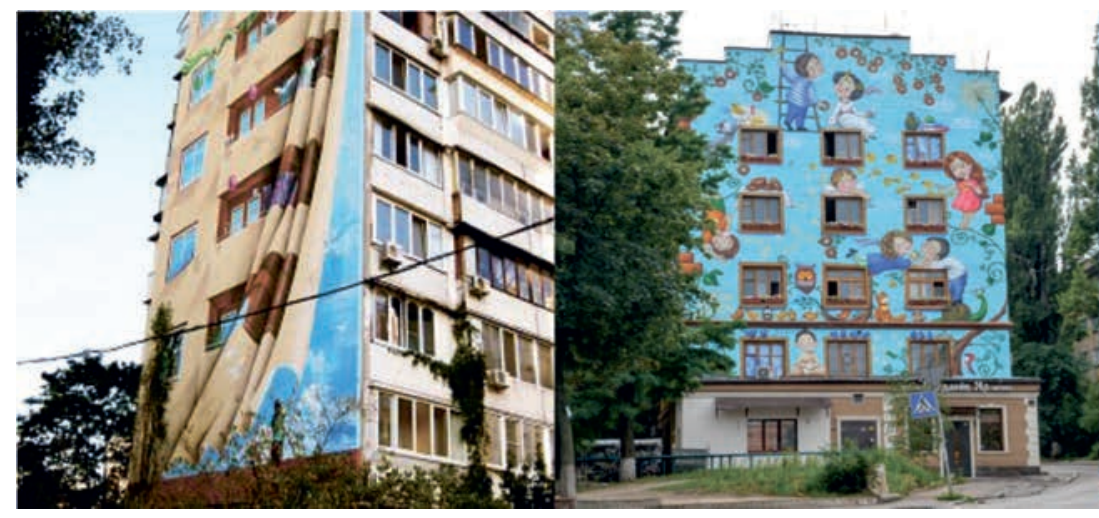

a

II. 9. Examples of solutions for buildings of different functional purposes:

a - residential, https://my-obolon.kiev.ua/dostoprimechatelnosti/rekordnoe-po-razmeram-graffiti-na-fasade-doma.html

b - public, https://lookmytrips.com/572a0d1aff936737a90738ab/mural-zdes-zhivet-liubov-ff9367

c - industrial, https://zeft.in.ua/murali-svyatoshinskogo-rajonu-kiyiv/ (access: 12.11.2021)
2. At the building level, the following typological classifications of murals should be distinguished:

2.1. By functional purpose of the building (residential, public, industrial)

The functional purpose of a building (residential, public, Industrial) significantly affects the theme and graphic language of images, because it is the background of a building for a certain purpose that often dictates appropriate compositional and artistic-figurative solutions. (II. 9)

\subsection{With or without consideration of the architectonics of the building}

Images of murals can be subordinated to the general architectonics of buildings, namely the location of loadbearing structures, entrances, windows, doors, and so on (II. 10)

Murals are made without taking into account the architectonics of buildings, windows, doors and other architectural elements are much more popular when artists work on images and reproduce the idea, despite the architectural details and ignoring them. In this case the plane they selected becomes a solid canvas (II. 11)

\section{3. With or without consideration of the building's entrance group}

Separately, we must identify popular murals that are created for a specific type of activity of a particular enterprise. Most often, such images are placed on its entrance group and meaningfully hint or artistically "tell» about a particular institution that is located in the building. In other words the mural becomes an attractive business card. (II. 12)

But it is not always possible to distinguish the entrance group of the enterprise compositionally and architecturally, and in this case, according to the general idea, thematic images of murals are located simply on the planes of buildings, sometimes including entrance zones in the organization of a general compositional solution. (II. 13) 


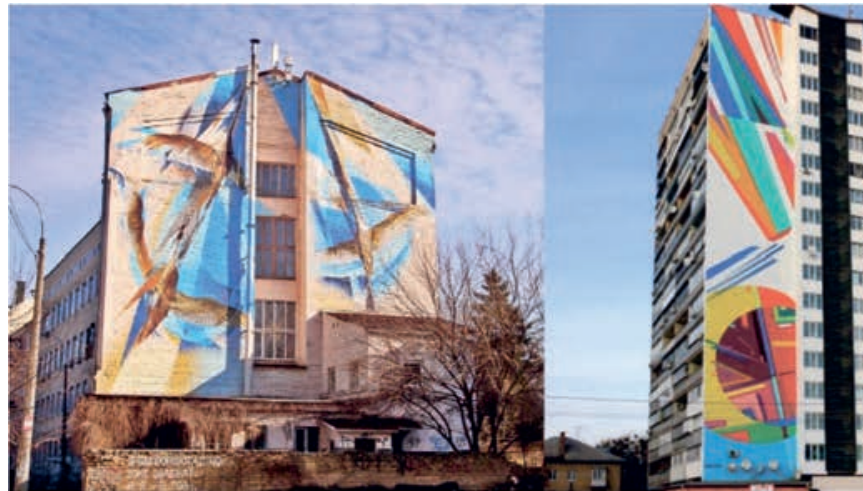

b

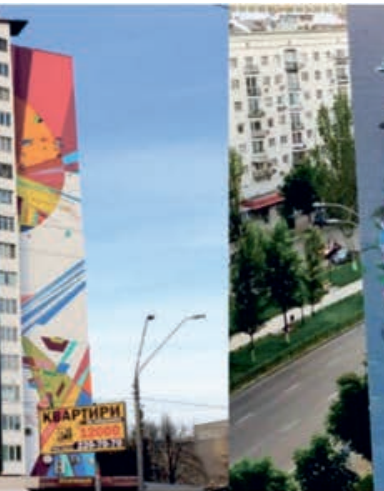

C

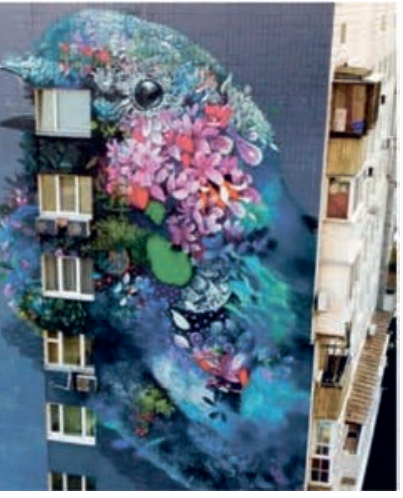

II. 10. Murals that take into account the architectonics of the building: a - https://zeftin.ua/murali-shevchenkivskogo-rajonu-kiyiv/

b - https://zeft.in.ua/murali-svyatoshinskogo-rajonu-kiyiv/

c - https://dayting.com.ua/ru/muralyi-na-pecherske-v-gorode-kiev (access: 12.11.2021)

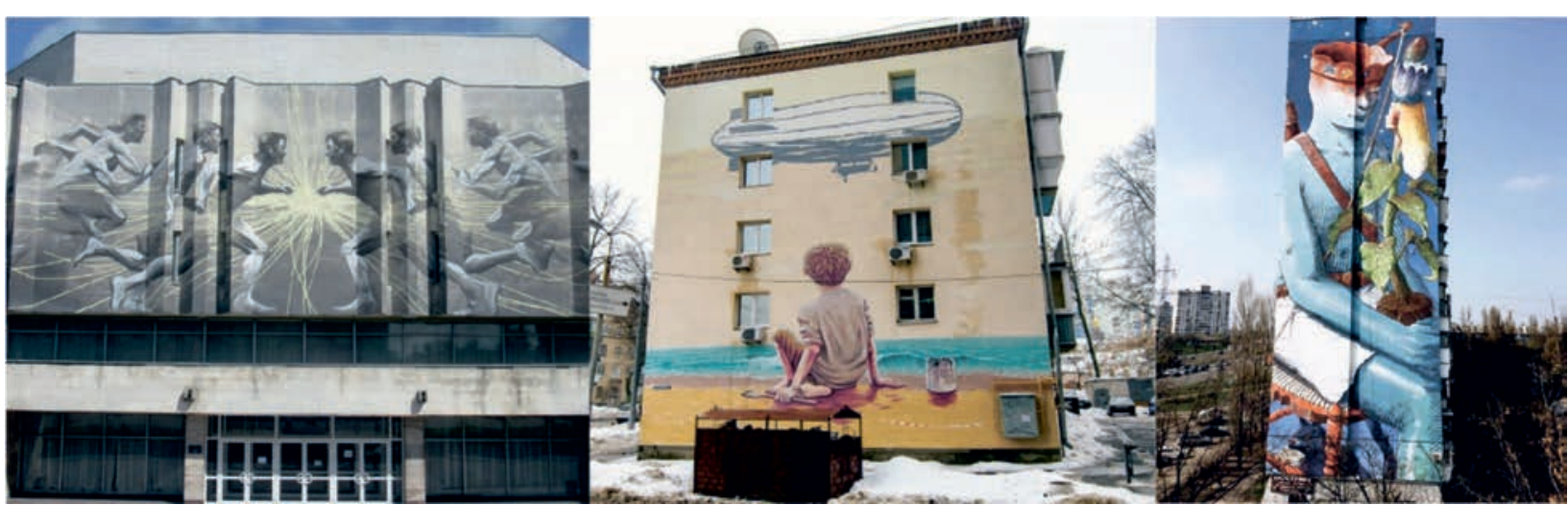

b
C

II. 11. Murals that do not take into account the architectonics of the buildings:

a - https://kpi.ua/ru/ckm-mural

b - https://zeft.in.ua/murali-pecherskogo-rajonu-kiyiv/

c - https://whattoseeinukraine.blogspot.com/2020/06/blog-post_28.html (access: 12.11.2021)

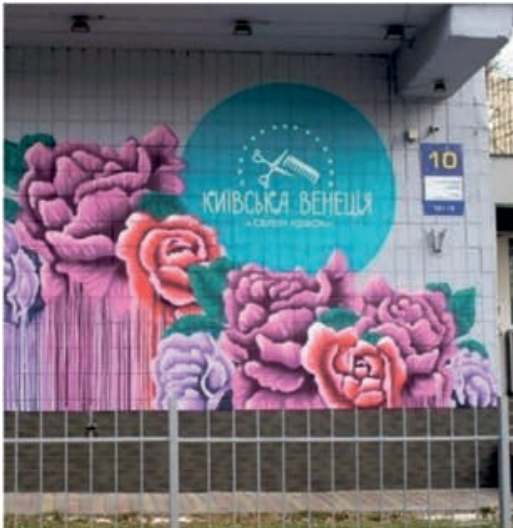

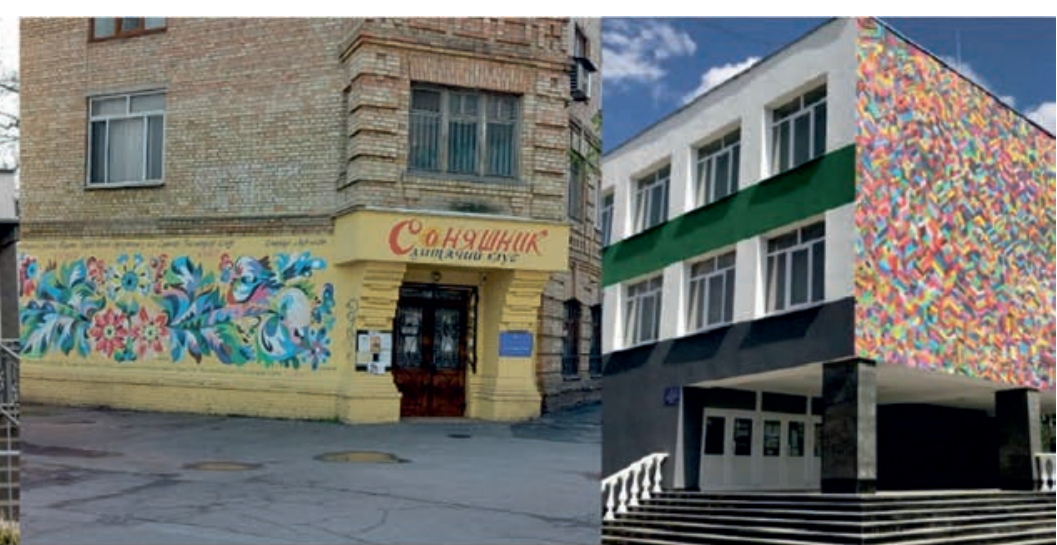

II. 12. Murals that take into account building's entrance group:

a - https://www.utart.com.ua/uk/kiivska-veneciya/

b - https://kyiv.dityvmisti.ua/dytiachyi-klub-soniashnyk/

c - https://darn.kyivcity.gov.ua/news/19360.html (access: 12.11.2021) 


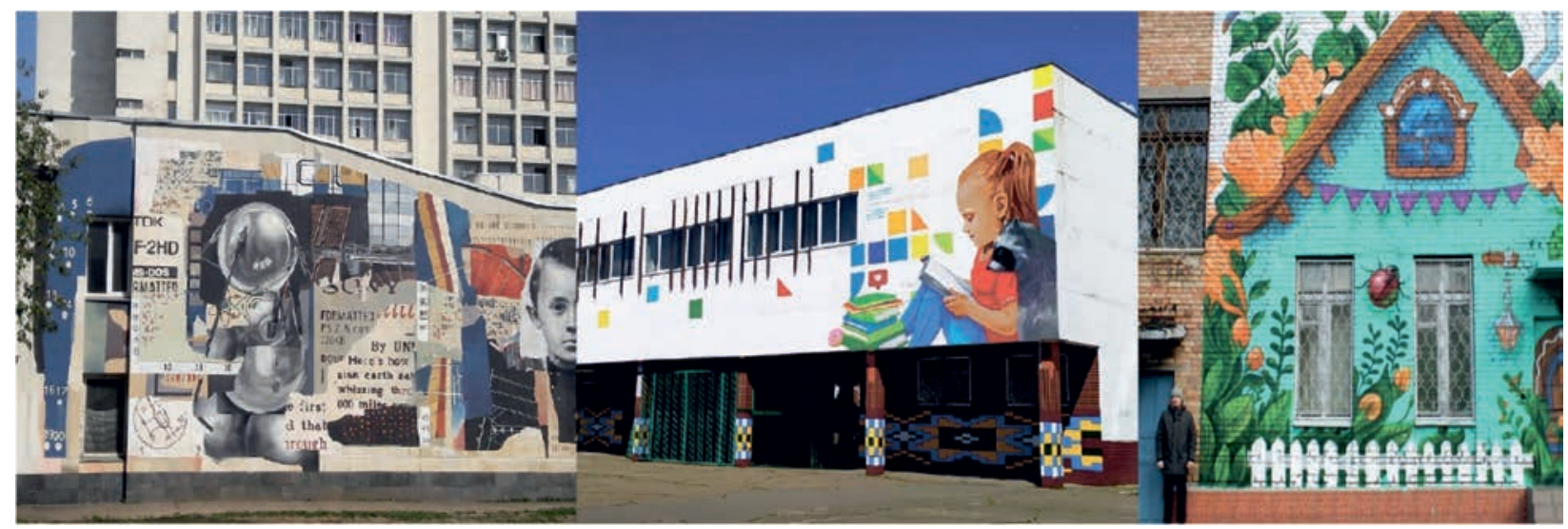

a

b

C

II. 13. Murals that do not take into account building's entrance group:

a - https://kpi.ua/ru/1723-1

b - https://desn.kyivcity.gov.ua/gallery/2316.html

c - https://m.day.kyiv.ua/uk/news/260319-u-kyyevi-zyavyvsya-pershyy-mural-z-dopovnenoyu-realnistyu-foto (access: 12.11.2021)

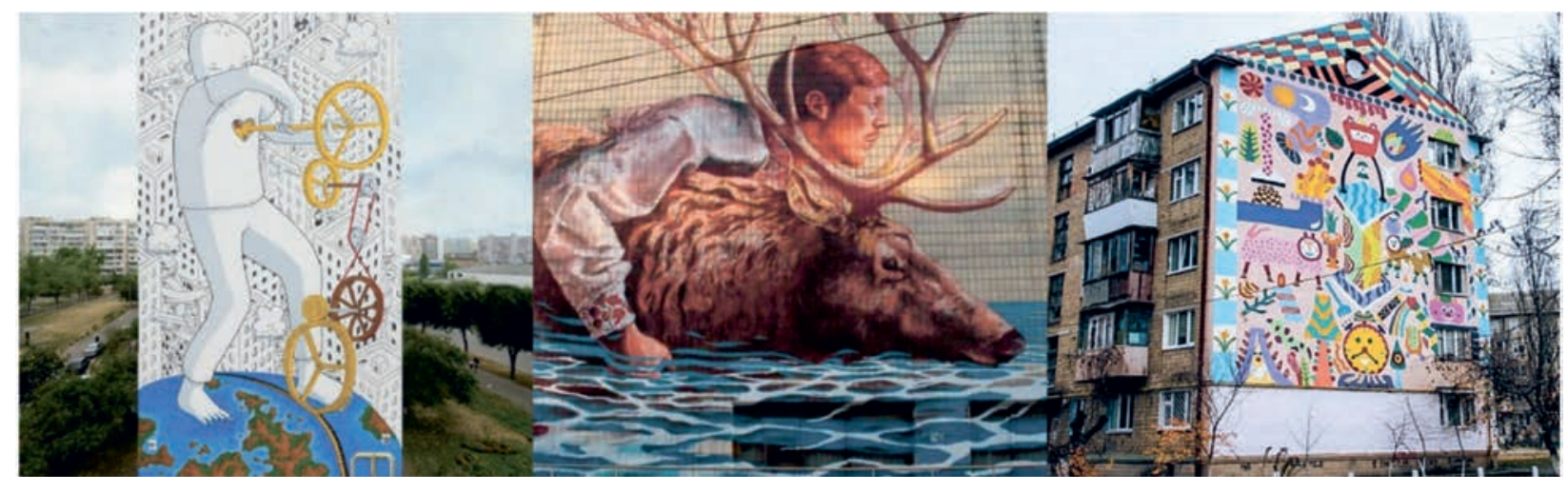

C

II. 14. Murals made in various artistic techniques:

a - graphic images, https://kievvlast.com.ua/news/v_stolice_na_odnom_iz_domov_pojavilas_mural_o_ljubvi41748

b - painting, https://vkieve.net/street-art/mural-s-olenem-na-zdanii-ses

c - decorative, https://zeft.in.ua/murali-svyatoshinskogo-rajonu-kiyiv/ (access: 12.11.2021)

\section{Classification of murals by image subject}

The main thematic load of mural images (mentioned at the beginning of the article) has remained unchanged for over 100 years since its inception. Modern researchers of murals only state the fact of adjusting their thematic and semantic content according to socio-political changes in a country. In the murals of Kyiv, all the basic provisions for their creation are clearly monitored, namely: social orientation-focusing on the most acute problems of society; patriotic component, which also performs the educational function of exalting the dignity of people, reminding of their own history and self-identification in the modern world; philosophical-reproducing certain ideas of the customer or author of the mural, which causes powerful emotions and reflections in the audience; religious - reminds people of eternal values and spiritual peace. (II. 1, 2, 11)

\section{Classification of murals by artistic and figurative solutions}

To reproduce compositional ideas, artists use all design and artistic tools - from basic elements: dots, lines and planes with different textures and colors to complex compositional constructions with multi-layered images in various graphic techniques. Silhouette forms and counter forms are used, classic contrasts of white and black, various combinations of colors are experimented with. Graphic, pictorial and decorative solutions remain the main means of expression, and the most valuable thing in murals is the ability to combine several artistic means simultaneously in one project.

Graphic contrasting black-and-white and monochrome compositions using lines and dots differ significantly from pictorial ones. Graphic murals look more poster, applicative, while in paintings there is a volume with chiaroscuro, colorful colors, textures, a sense of aerial perspective. Decorative murals reproduce national ornaments, elements of decorative painting and imitate the style of images of famous masters of folk painting (II. 14)

\section{Classification of murals by execution technique A variety of reproduction techniques greatly help to combine the means of image and imitate certain}


artistic styles. Modern materials significantly speed up and simplify work with large vertical planes and volumes, unlike classical fresco painting. When creating murals, masters use both ordinary art and painting tools: brushes, rollers, various mounting tapes, and special aerosol cans with paints or just special paints suitable for working on the street. Paints should be as resistant as possible to weather changes. One of the highest in Europe Mural $-78 \mathrm{~m}$ is made by special exterior paint company Tikkurila. (II. $6 \mathrm{c}$ )

A popular tool in the work is pre-prepared stencils according to the approved sketch, which significantly reduces the working time. Also, certain requirements relate to the preparation of surfaces for applying images. Each surface has its own characteristics and their preparation for work is also different. The walls of old buildings require prior renovation and leveling, while modern buildings have flat, smooth surfaces. Each of the authors of murals has their own style, handwriting and the choice of reproduction technique depends entirely on their personal preferences.

\section{CONCLUSION}

The mural phenomenon has an active influence on the quality of urban spatial structures in urbanized areas, as well as the perception and quality of human life. Filling empty vertical planes on buildings since Soviet times has attracted artists to implement artistic and aesthetic projects.

The article reveals and examines a brief history of the development of modern murals and the foundations of their typology on the example of the city of Kiev. Their classification is determined and considered according to the following characteristics: by urban planning/ environmental characteristics (at the urban planning level); by placing it against the background of a building (at the building level); by topic; by compositional and artistic-figurative solutions; according to the technique of execution. With all the variety of their possible artistic and decorative solutions and methods of use, an important condition is to achieve aesthetic expressiveness and attractiveness, as well as the stylistic unity of the composition of the urban environment. Such review will help to form a holistic understanding of the phenomenon of murals in the space of the urban environment and will allow to systematize existing knowledge and concepts, practices and prospects of means and methods of its formation and development.

\section{REFERENCES}

[1] Gralińska-Toborek A. Experience of Art in Urban Space, Lodz: Biblioteka Publishing House, 2014. - p. 85-99

[2] Gastman R., Neelon C., Smyrski A. Street World: Urban Culture and Art from Five Continents, New York: Abrams Books, 2007. p. 384

[3] Kais Z. W. Social semantics of the urban world: graffiti symbolism: author's ref. dis. ... cand. philos. Sciences: 09.00.03/Z. V. Kais; NAS of Ukraine, Institute of Philosophy. G.S. Frying pans. Kyiv, 2015. $-20 p$

[4] Shpetna S.A. Socio-cultural phenomenon of the mural as a call for dialogue and discussion, Bulletin of Luhansk Taras Shevchenko National University. Philological Sciences, 2020, 3 (334): p. 150156

[5] Kolisnyk, A. V., Ponomarova, N.S. (2019) Murals as a way of social communication, Comparison of the world experience. Art and design. 2. p. 62-73.

[6] Havrylash I. S. Murals and graffiti in modern Ukraine: features and differences, Culture of Ukraine, 2018 (62) p. 235-244.

[7] Lolina N.A. Mural in modern urban spase: Challenge or Reflection of cultural reality, Ministry of education and science of Ukraine MP Dragomanov national university of pedagogy, 2019, p.84-87.

[8] Piotr Gryglewski,Yulia Ivashko, Denys Chernyshev, Peng Chang, Andrii Dmytrenko. Art as a message realized through various means of artistic expression, Art Inquiry. Recherchessur les arts 2020, vol. XXII, pp.57-88.

[9] Kozub W. Mural - a contemporary architectural detail, Proceedings from Aktualni problemy suchasnoho dyzainu [Actual problems of modern design]: materialy Mizhnarodnoi naukovo praktychnoi konferentsii (20 kvitnia 2018 r.). Kyiv: KNUTD, 2018. p. 33-36.

[10] Ostapenko, A.A. Kyiv mural art / AA Ostapenko, OA Pivovarenko, // Scientific achievements of youth - solving problems of human nutrition in the XXI century: materials of the 83rd international scientific conference of young scientists, graduate students and students, April 5-6, 2017 - Kyiv: NUHT, 2017, Part 4. - p. 51-52. 